\title{
ANALISIS LOST OPPORTUNITY (LO) BAUKSIT INDONESIA
}

\author{
Lost Opportunity (LO) Analysis of Indonesia Bauxite
}

\author{
HARTA HARYADI \\ Puslitbang Teknologi Mineral dan Batubara \\ Jalan Jenderal Sudirman 623, Bandung 40211 \\ Telp. 022 6030483, Ext. 206, Fax. 0226003373 \\ e-mail: hartah@tekmira.esdm.go.id
}

\begin{abstract}
ABSTRAK
Tujuan dari studi ini adalah untuk menghitung kesempatan laba yang diperoleh bila bauksit yang diekspor dalam bentuk olahan (alumina). Ketika melakukan ekspor bahan mentah bauksit, perusahaan hanya menghitung laba yang bisa mereka peroleh, maka dihitunglah seluruh pengeluaran dan pemasukan dan sisanya akan menjadi laba atau kerugian. Perusahaan ketika mulai berproduksi hingga mengekspor selalu menghitung dari segi laba dan rugi saja. Perusahaan jarang memperhitungkan lost opportunity (LO) atau kesempatan memperoleh laba yang hilang kalau bauksit yang diekspor itu dalam produk olahan. Sampai saat ini, Indonesia belum memiliki industri pengolahan bauksit menjadi alumina, sehingga produksi bauksit seluruhnya diekspor dalam bentuk mentah, sementara alumina terus diimpor untuk memenuhi kebutuhan industri aluminium di dalam negeri. Untuk mengetahui kondisi perdagangan luar negeri bauksit, dilakukan analisis lost opportunity (LO). Metode yang digunakan untuk menghitung LO, dilakukan dengan menggunakan rumus $\mathrm{LO} 1=(\mathrm{V}$ ekspor X P impor) - (V ekspor X P ekspor). Parameter yang diukur adalah menghitung volume ekspor bauksit dikalikan harga impor dikurangi volume ekspor dikalikan harga ekspor. Dari parameter ini dapat diketahui berapa kesempatan laba yang hilang karena bauksit tersebut diekspor dalam bentuk mentah bukan sebagai alumina. Pada tahun 2007 diperoleh nilai LO sebesar US\$10.081.979.338 dan tahun 2012 diperoleh nilai LO sebesar US18.539.227.798. Hasil nilai LO tersebut, menunjukkan bahwa Indonesia kehilangan kesempatan untuk memperoleh laba yang besar karena ekspor dalam bentuk mentah dengan harga jual yang murah. Apabila industri pengolahan bauksit menjadi alumina dapat segera dilaksanakan, kemungkinan akan memperoleh laba besar yang selama ini tidak diperoleh, dan tentu meningkatnya pendapatan nasional.
\end{abstract}

Kata kunci : lost opportunity, bauksit, alumina, ekspor, impor

\begin{abstract}
The aim of this study is to calculate the profit opportunities that can be obtained when bauxite is exported in processed form (alumina). When exporting the raw material bauxite, the company only calculate the return they can get, then counted was all expenditures, all income and the rest will be as a gain or a loss. When the company starts production untul to export, it always calculate in terms of profit and loss only. Company rarely take into account the lost opportunity (LO) or lost profit opportunity if the bauxite is exported in the processed form. To date, Indonesia has no yet industrial processing of bauxite into alumina, so that bauxite production entirely exported in raw form, while alumina continue to be imported to meet the needs of the aluminum industry in the country. To determine the condition of the foreign trade of bauxite, it is important to do an analysis of lost opportunity (LO). The method used to calculate the LO, is done by using the formula $L O 1=(V$ export X P import $)-($ V export X P export). Parameters measured were calculating the volume of export multiplied by import prices, and reduced export volume multiplied by export prices. From these parameters can be determined how much profit opportunity is lost because bauxite is exported in raw form rather than in alumina. In 2007 obtained a value of US \$10,081,979,338 LO. While LO values obtained in 2012 amounted US18.539.227.798. Results of the $L O$ value, shows that Indonesia lost the opportunity to earn big profits due to the exports in raw form with a cheap price. If the processing of bauxite into alumina can be immediately implemented, it would likely be able to obtain large profits, and ofcourse the increase in national income.
\end{abstract}

Keywords: lost opportunity, bauxite, alumina, exports, imports 


\section{PENDAHULUAN}

Indonesia memiliki sumber daya dan cadangan bauksit yang cukup besar. Total keseluruhan sumber daya bauksit Indonesia sebesar 941,24 juta ton dan cadangan 381,35 juta ton dengan kadar $\mathrm{Al}_{2} \mathrm{O}_{3}$ berkisar $27-55 \%$ (Tabel 1 ).

Pada tahun 2013, sumber daya bauksit dunia sebesar 43,80 miliar ton dan Indonesia menempati urutan ke 8 terbesar dunia dengan jumlah 1,322 miliar ton $(2,96 \%)$, sedangkan negara terbesar adalah Guinea sebesar 11,56 miliar ton (26,4\%), diikuti oleh Australia sebanyak 9,37 miliar ton $(21,4 \%)$, Brasil 4,07 miliar ton (9,3\%), Vietnam sebesar 3,28 miliar ton $(7,5 \%)$, Jamaika 3,11 miliar ton $(7,1 \%)$ dan Cina sebesar 2,30 miliar ton (5,25\%), dan India dengan sumber daya sebesar 1,40 miliar ton $(3,19 \%)$ dan negara-negara lainnya dengan total 12,35 miliar ton $(28,20 \%)$ lihat Gambar 1 .

Permasalahan yang dihadapi Indonesia walaupun memiliki sumber daya bauksit yang besar, sampai saat ini transaksi perdagangan luar negeri bauksit belum memberikan sumbangan yang signifikan bagi neraca pendapatan nasional, disebabkan seluruh produksi bauksit yang dihasilkan dijual dalam bentuk mentah, khususnya ke Cina dan Jepang. Di sisi lain Indonesia mengimpor alumina dari Australia untuk memenuhi industri peleburan aluminium PT. Inalum sebesar 514.180,00 ton pada tahun 2007, dan pada tahun 2012 menjadi 1.000.715,00 ton. Kondisi ini menyebabkan selama tahun 2007-2012 telah kehilangan kesempatan untuk memperoleh laba dari nilai perdagangan luar negeri bauksit yang sangat besar (LO besar). Di samping itu, kondisi tersebut mengurangi daya tahan dan daya saing industri lokal, serta merugikan negara karena nilai tambah pengolahan atau pemurnian komoditas tambang bauksit menjadi milik negara importir, yang telah memiliki industri pengolahan alumina.

Selama tahun 2007-2012, ekspor bauksit Indonesia terus mengalami peningkatan. Bauksit yang diekspor ke berbagai negara dalam bentuk bijih, sedangkan impor dalam bentuk alumina yang harganya lebih tinggi dari harga bauksit ekspor (LO besar). Kondisi ini menyebabkan LO besar, yang secara tidak langsung Indonesia kehilangan kesempatan memperoleh devisa negara yang cukup besar sekaligus kehilangan sumber daya bauksit yang cukup besar.

Berdasarkan data dari Direktorat Jenderal Mineral dan Batubara (2013), selama periode 2007-2012 ekspor bauksit Indonesia cenderung meningkat. Tahun 2007 volume ekspor bauksit Indonesia telah mencapai 17.031.809,00 ton. Sedangkan tahun 2011 ekspornya meningkat sangat besar dan telah mencapai 40.796.224,10 ton, namun pada tahun 2012 ekspor menurun kembali hingga mencapai 29.688.890,00 ton, penurunan ini disebabkan terbitnya Permen ESDM No. 7 dan 12 Tahun 2012 yang melarang ekspor dalam bentuk produk mentah (Tabel 2 dan 3). Selama tahun 2007-2012, nilai LO bauksit Indonesia sangat besar. Dengan mempertimbangkan hilangnya besaran devisa tersebut maka dapat dijadikan alasan mengapa pembangunan smelter alumina perlu segera dilakukan dan Indonesia sudah memiliki pabrik peleburan aluminium PT Inalum.

Untuk mengetahui permasalahan perdagangan luar negeri bauksit (ekspor dan impor) maka dilakukan analisis lost opportunity (LO). Tujuan dari studi ini adalah menghitung kesempatan laba yang dapat

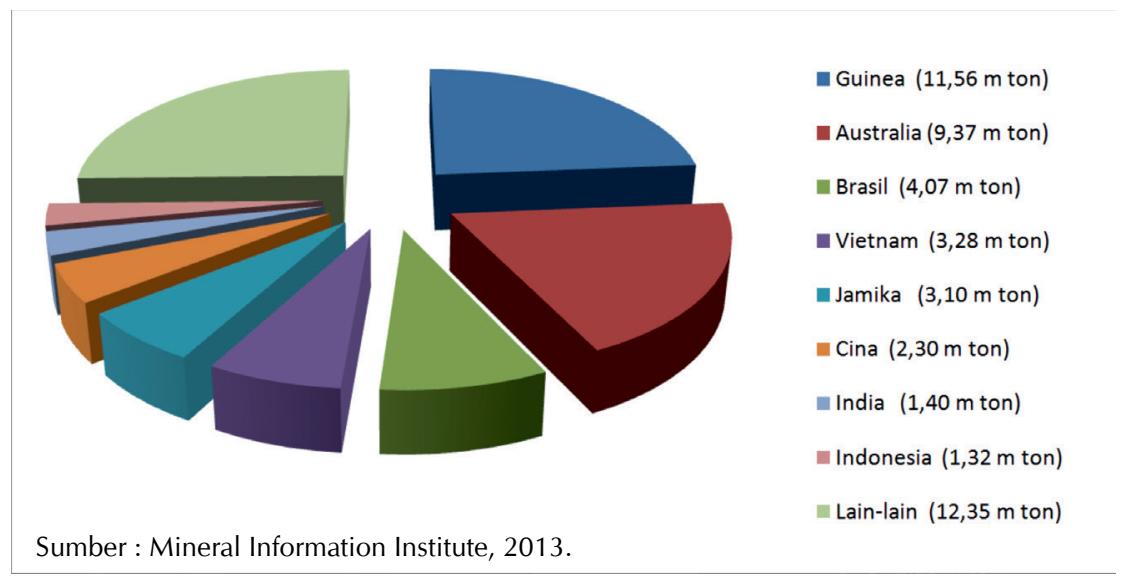

Gambar 1. Sumber daya dan cadangan bauksit dunia, 2013 
Analisis Lost Opportunity (LO) Bauksit Indonesia, Harta Haryadi

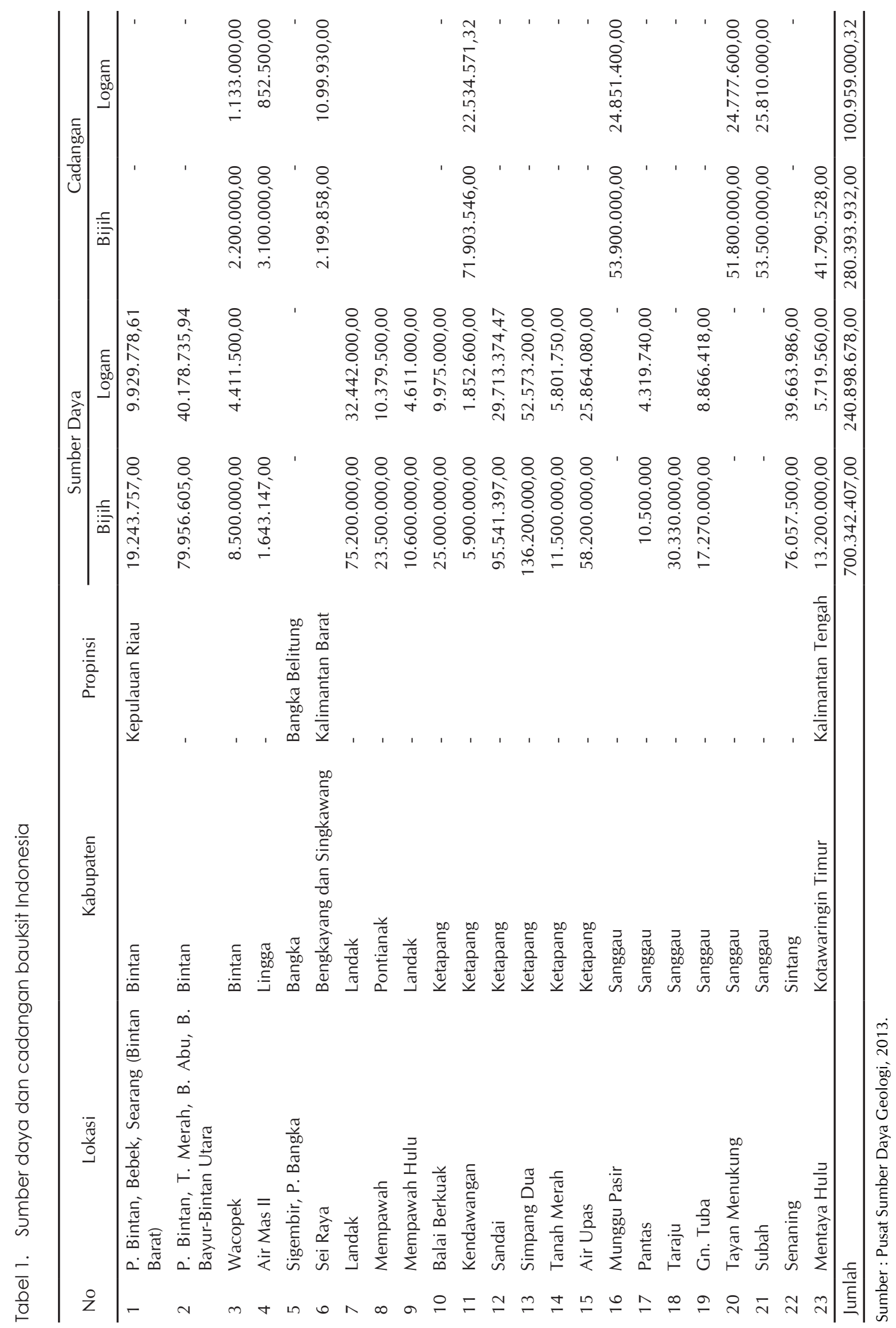


diperoleh bila bauksit yang diekspor dalam bentuk olahan (alumina).

Berdasarkan data PT. Antam (2011) selaku produsen bauksit terbesar dan tertua di Indonesia dalam laporannya, saat ini sudah mengembangkan pabrik pengolahan bauksit menjadi chemical grade alumina (CGA) di Tayan dengan kapasitas 300.000 ton yang sudah berproduksi mulai tahun 2013. Berdasarkan perhitungan PT. Antam, untuk menghasilkan 300.000 ton CGA dibutuhkan bauksit tercuci (washed bauxite) sebanyak 850.000 ton dan dibutuhkan investasi (capital expenditure) sebesar US\$ 450 juta, sehingga untuk setiap ton CGA yang dihasilkan dibutuhkan investasi sebesar US\$ 1.500. Menurut PT. Antam, dari setiap ton bauksit yang diproduksi menjadi CGA akan meningkatkan nilai tambah hingga 9,92 kali dibandingkan jika hanya menjual bauksit dalam bentuk bijih, hal ini akan mengurangi nilai LO ANTAM sebesar US\$ 200 juta apabila ekspor dalam bentuk bijih dan mengurangi nilai LO yang selama ini dihadapi Indonesia dalam sektor pertambangan bauksit. Selain sudah memproduksi chemical grade alumina (CGA), saat ini PT. Antam sedang mengembangkan pabrik pengolahan bauksit menjadi smelter grade alumina (SGA) di Mempawah dengan kapasitas 2.000.000 ton yang akan berproduksi akhir tahun 2017 bekerjasama dengan PT. Inalum.

\section{Kondisi Bauksit Indonesia}

Sumber daya bauksit yang dimiliki Indonesia cukup besar dengan total keseluruhan sebesar 941,24 juta ton dan cadangan 381,35 juta ton dengan kadar $\mathrm{Al}_{2} \mathrm{O}_{3}$ berkisar 27-55\%, yang tersebar di Kepulauan Riau, Bangka Belitung, Kalimantan Barat, dan Kalimantan Tengah (Pusat Sumber Daya Geologi,
2013). Dengan jumlah tersebut Indonesia menempati urutan ke 8 terbesar dunia dengan persentase $(2,96 \%)$, sedangkan negara terbesar adalah Guinea $(26,4 \%)$, Australia $(21,4 \%)$, Brasil $(9,3 \%)$, Vietnam $(7,5 \%)$, Jamaika $(7,1 \%)$, Cina $(5,25 \%)$, dan India $(3,19 \%)$ (Mineral Information Institute, 2013).

Setiap negara memiliki sumber daya alam yang berbeda-beda satu sama lain yang tidak terdapat di negara lain. Suatu negara akan membutuhkan komoditi yang tidak tersedia di negaranya tetapi tersedia di negara lain, maka negara tersebut akan melakukan perdagangan atau pertukaran komoditi dengan negara lain. Terjadilah kegiatan ekspor dan impor tiap negara. Perdagangan internasional ekspor impor adalah kegiatan yang dijalankan eksportir maupun produsen eksportir dalam transaksi jual beli suatu komoditi dengan orang asing, bangsa asing, dan negara asing. Kemudian penjual dan pembeli yang lazim disebut eksportir dan importir melakukan pembayaran dengan valuta asing (Adie, 2010).

Ketergantungan Indonesia pada bahan baku impor sektor pertambangan untuk industri di dalam negeri cukup besar disebabkan belum adanya industri yang mengolah bahan baku menjadi barang jadi. Menurut Salvatore (2007), salah satu aktivitas perekonomian yang tidak dapat dilepaskan dari perdagangan internasional adalah aktivitas ekspor dan impor, baik yang sifatnya masuk maupun keluar, dari suatu negara. Ketika terjadi aktivitas perdagangan internasional berupa kegiatan ekspor dan impor maka besar kemungkinan terjadi perpindahan produk jadi dari negara eksportir ke negara importir yang disebabkan oleh kemampuan negara eksportir dalam teknologi pengolahan bahan baku menjadi barang jadi. Kinerja perdagangan Indonesia yang semakin menurun, terlihat dari surplus neraca perdagangan yang semakin menurun (defisit) dari

Tabel 2. Kondisi pemasokan dan kebutuhan bauksit Indonesia

\begin{tabular}{ccccc}
\hline Tahun & $\begin{array}{c}\text { Produksi Bijih } \\
\text { (ton) }\end{array}$ & $\begin{array}{c}\text { Konsumsi Alumina } \\
\text { (ton) }\end{array}$ & $\begin{array}{c}\text { Ekspor Bijih } \\
\text { (ton) }\end{array}$ & $\begin{array}{c}\text { Impor Alumina } \\
\text { (ton) }\end{array}$ \\
\hline 2007 & $19.406 .405,00$ & $247.480,00$ & $17.031 .809,00$ & $514.180,00$ \\
2008 & $18.005 .502,00$ & $734.422,45$ & $16.960 .964,00$ & $713.750,50$ \\
2009 & $16.083 .258,00$ & $542.611,00$ & $14.889 .466,83$ & $769.056,00$ \\
2010 & $29.595 .049,00$ & $602.725,00$ & $27.570 .857,55$ & $817.800,59$ \\
2011 & $40.995 .000,00$ & $685.420,00$ & $40.796 .224,10$ & $876.565,57$ \\
2012 & $30.495 .000,00$ & $711.477,00$ & $29.688 .890,00$ & $1.000 .715,80$ \\
\hline
\end{tabular}

Sumber : Direktorat Jenderal Mineral dan Batubara, 2013

Kementerian Perdagangan, 2013

Badan Pusat Statistik, a, b dan c, 2013 


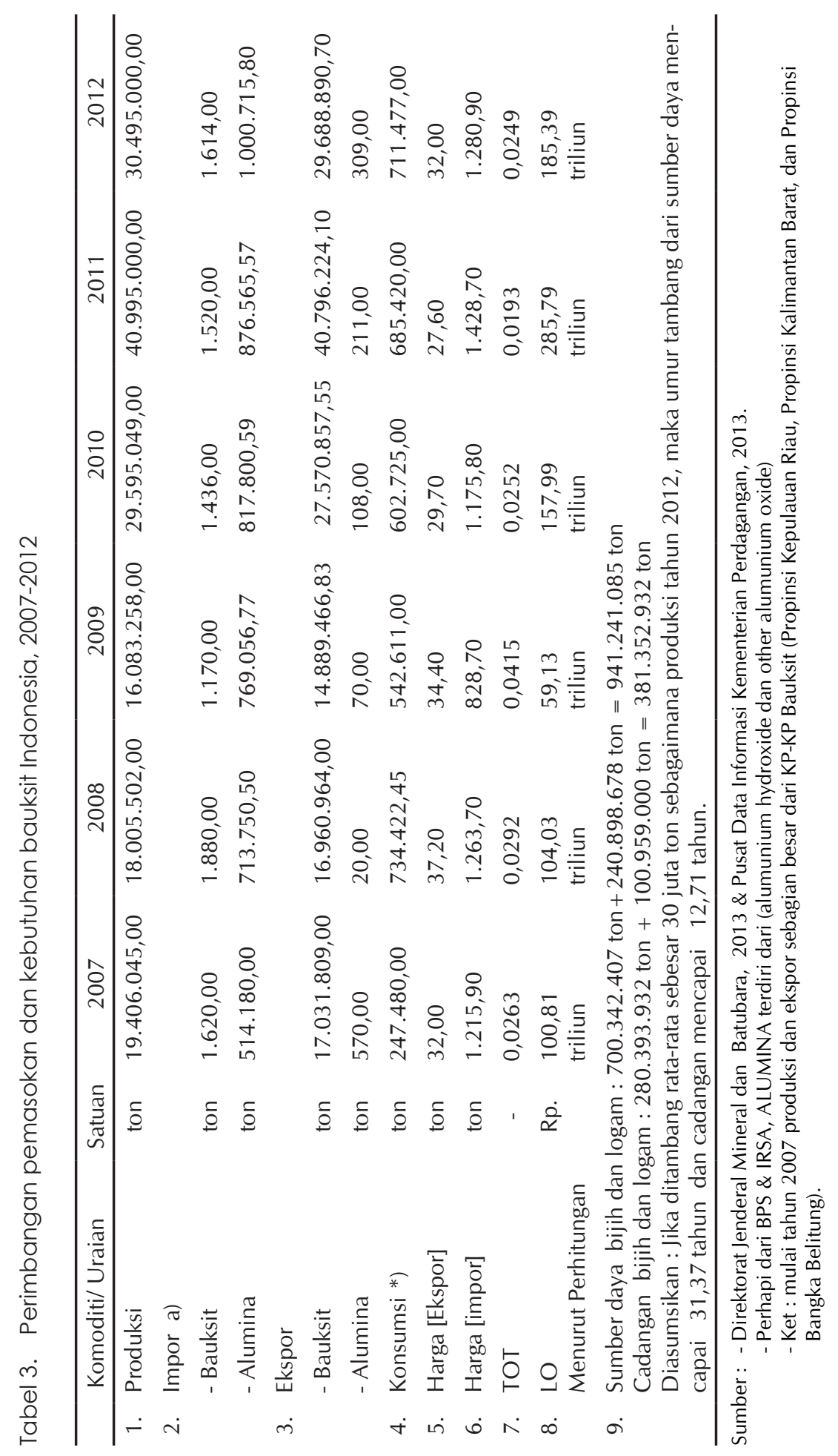


tahun ke tahun. Hal tersebut menunjukkan bahwa negara Indonesia sangat tergantung dengan produkproduk impor.

Aliran investasi asing khususnya industri pengolahan (smelter) di sektor pertambangan yang diharapkan mampu mendorong peningkatan industri dalam negeri, khususnya sektor pertambangan belum sepenuhnya dapat terwujud. Hal tersebut disebabkan investor asing yang masuk ke Indonesia cenderung berinvestasi kepada industri non-pertambangan. Gubernur Bank Indonesia, dalam Viva Business News (2012), menyatakan bahwa masuknya investasi asing ke Indonesia lebih dominan mengarah pada pasar dalam negeri (industri konsumsi), tidak berorientasi ekspor (industri pengolahan). Hal ini berdampak pada timpangnya struktur ekspor dan impor Indonesia. Hal tersebut menimbulkan ketidakseimbangan antara jumlah ekspor dan impor Indonesia yang berakhir pada terjadinya defisit neraca perdagangan Indonesia.

Sejalan dengan Laporan Perekonomian Indonesia 2014 yang menyatakan bahwa kinerja ekspor yang makin menurun tetepi jumlah impor makin meningkat, khususnya barang modal dan bahan baku. Hal tersebut berdampak pada defisit neraca perdagangan. Sejalan dengan peningkatan impor, investasi asing mengalami peningkatan yang mampu menutupi defisit neraca transaksi berjalan. Dampak aliran masuk modal asing ke sektor riil secara umum terjadi melalui perubahan nilai tukar riil mata uang domestik (nilai tukar setelah memperhitungkan tingkat harga di negara-negara terkait). Nilai tukar riil mata uang domestik yang cenderung terapresiasi dapat berdampak negatif terhadap kinerja ekspor (melemahkan daya saing ekspor dari sisi harga), namun dapat mendorong kenaikan volume impor (Bank Indonesia, 2015). Berdasarkan laporan ini, dapat disimpulkan bahwa terdapat ketidaksesuaian harapan pemerintah terkait perdagangan internasional (ekspor dan impor) dan investasi asing di Indonesia yang orientasinya domestik. Permasalahan tersebut melatarbelakangi untuk melakukan kajian Lost Opportunity bauksit, untuk mengetahui seberapa besar kesempatan yang hilang apabila ekspor bauksit sudah dalam bentuk olahan (alumina).

Perdagangan luar negeri (ekspor dan impor) dan investasi asing (industri pengolahan) merupakan dua aktivitas penting bagi perekonomian Indonesia yang memiliki keterkaitan satu sama lainnya. Mengingat kedua aktivitas tersebut berpotensi memberikan kontribusi yang besar terhadap peningkatan per- ekonomian Indonesia (PDB).

Kondisi perdagangan luar negeri dapat dilihat dari proporsi nilai total ekspor dan impor terhadap PDB yang memengaruhi arus investasi asing pada suatu negara. Menurut Pramudita (2012), dampak perdagangan luar negeri ini, dalam jangka panjang berpengaruh terhadap pertumbuhan ekonomi secara tidak langsung.

Menurut Antoni (2008) aktivitas ekonomi antar negara dan perniagaan, memiliki dua aspek hubungan antara investasi asing dengan perdagangan internasional, yaitu (1) investasi asing merupakan pengganti atau pelengkap perdagangan internasional; dan (2) investasi asing menjadi penyebab perdagangan internasional atau sebaliknya. Dalam aspek yang pertama, model Heckscher - Ohlin Samuelson (H-O-S) menyatakan bahwa perdagangan internasional dapat menggantikan pergerakan faktor pengeluaran antar negara yang salah satunya berupa ekspor. Model ini menjelaskan bahwa perdagangan komoditi suatu negara melibatkan pertukaran faktor pengeluaran antara negara secara tidak langsung.

Secara umum, aliran investasi dari luar negeri berupa investasi asing akan berpengaruh terhadap produktivitas nasional, disebabkan adanya transfer teknologi, manajemen dan keahlian yang dibawa oleh negara investor. Peningkatan produktivitas ini akan berdampak pada peningkatan output baik itu yang dikonsumsi domestik maupun yang diekspor. Selain itu, investasi asing dapat merangsang ekspor domestik melalui keterkaitan industri (industries linkage), khususnya melalui keterkaitan ke belakang, yaitu membeli input antara buatan lokal untuk menghasilkan ekspor (Hailu, 2010).

Efek ini menciptakan stimulus permintaan yang kuat untuk perusahaan domestik dan mempromosikan ekspor. Sebaliknya, peningkatan ekspor menyebabkan peningkatan produktivitas yang berarti pula peningkatan pertumbuhan ekonomi. Pertumbuhan ekonomi yang tinggi bisa menjadi salah satu daya tarik investor untuk menanamkan modalnya. Selain itu, kinerja ekspor yang baik bisa menjadi daya tarik tersendiri bagi investor asing karena menunjukkan tingkat daya saing internasional yang baik dan terbukanya peluang untuk menanamkan modalnya pada sektor- sektor yang berorientasi ekspor tersebut.

Selain itu, hubungan antara impor dan jenis output investasi asing bisa positif atau negatif. Jika output investasi asing cenderung melengkapi produk lain- 
nya yang diimpor, maka akan mendorong kenaikan impor. Namun, jika investasi asing terkonsentrasi pada industri substitusi impor, maka akan mengurangi impor karena barang yang diimpor sebelumnya sudah dapat diproduksi di negara bersangkutan oleh investor asing. Di sisi lain, peningkatan impor dalam suatu negara akan mendorong perusahaan substitusi impor yang telah beroperasi dalam negeri untuk berinovasi untuk bersaing dengan rival asing, sehingga meningkatkan efisiensi produktivitas. Peningkatan efiesiensi dan peningkatan permintaan impor pada akhirnya dapat menarik minat perusahaan asing untuk melakukan kegiatan investasi untuk memasok pasar.

\section{METODE}

\section{Jenis dan Teknik Pengumpulan Data}

Jenis data dalam penelitian ini adalah data kuantitatif berupa data ekspor, harga ekspor, nilai ekspor, data impor, harga impor, dan nilai impor. Sedangkan data ekspor dan data impor, jenis data menurut sumbernya adalah data sekunder yang diperoleh melalui studi pustaka maupun langsung dari instansi terkait dengan sektor pertambangan.

Untuk mengetahui kondisi ekspor dan impor bauksit, dilakukan tinjauan secara langsung kepada beberapa produsen bauksit yang berada di Propinsi Kepulauan Riau, antara lain PT. Bina Dompak Indah; PT. Bintang Cahaya Terang; PT. Danpac Resources; PT. Gunung Bintan Abadi; PT. Tunggul Ulung Makmur. PT. Dua Karya Abadi; PT. Alam Indah Purnama Panjang; PT. Kereta Kencana Bangun Perkasa; dan PT. Perjuangan. Sedangkan produsen bauksit di Kalimantan Barat adalah PT. Antam; dan PT. Harita Prima Abadi Mineral (Dinas Pertambangan Kepulauan Riau, 2013).

\section{Metode perhitungan LO}

Metode untuk mengetahui seberapa besar kesempatan untuk memperoleh laba yang hilang (LO) dari kondisi perdagangan luar negeri bauksit yang dilaksanakan selama ini dengan menggunakan persamaan yang dirumuskan sebagai berikut (Tulus dan Simon, 2004; Sugiarto dan Herlambang, 2006) :

$$
\begin{aligned}
& \mathrm{LO} 1=(\text { Veks X Pim })-(\text { Veks X Peks }) \\
& \mathrm{LO}=\text { Lost Opportunities; } \\
& \mathrm{V} \quad=\text { volume penjualan; }
\end{aligned}
$$

$$
\begin{array}{ll}
\mathrm{P} & =\text { harga penjualan } \\
\mathrm{eks} & =\text { ekspor; } \\
\mathrm{im} & =\text { impor; } \\
1 & =\text { tahun tertentu. }
\end{array}
$$

Ketika melakukan ekspor bahan mentah bauksit, perusahaan hanya menghitung dari segi laba dan rugi saja. Perusahaan jarang memperhitungkan LO atau laba yang sangat besar yang ditimbulkan oleh kesempatan tersebut. Misal, perusahaan melakukan ekspor bijih bauksit dengan modal Rp. 10 miliar tingkat laba bersih per bulan adalah Rp. 200 juta sehingga bisa dihitung tingkat BEP adalah 50 bulan. Dalam setahun perusahaan mendapatkan laba Rp. 2,4 miliar. Dan persentase laba perusahaan adalah $2 \%$ dari modal perbulannya.

Seandainya bauksit tersebut harus diolah maka memerlukan modal Rp. 100 miliar tingkat laba bersih per bulan adalah Rp. 2,5 miliar. Sehingga tingkat BEP nya adalah 40 bulan. Dalam setahun perusahaan mendapat laba Rp. 30,0 miliar. Dan persentase labanya adalah 2,5\% dari modal per bulannya.

Jika perusahaan memilih bisnis yang ke-1 dengan alasan karena tingkat risikonya lebih kecil dan lebih mempunyai prospek jangka panjang walaupun labanya lebih kecil, maka bisnis ke-2 (melalui pengolahan mineral) adalah LO (kesempatan yang hilang) yang tidak diperoleh oleh perusahaan, karena bisnis ke-2 ini tidak dilakukan oleh perusahaan.

Perusahaan kehilangan bisnis pengolahan bauksit karena modalnya dipergunakan untuk bisnis mineral mentah, sehingga modalnya tidak bisa untuk bisnis pengolahan mineral. Dikarenakan perusahaan memilih bisnis menjual bahan mentah, maka laba yang didapat dari bisnis 'menjual bahan mentah' sebesar Rp. 200 juta adalah cost opportunity (biaya yang timbul dari kesempatan).

Biaya peluang atau biaya ekonomi (cost opportunity) adalah suatu ukuran dari biaya ekonomi yang harus dikeluarkan dalam rangka memproduksi suatu barang atau jasa tertentu dalam kaitannya dengan alternatif lain yang harus dikorbankan. Misalnya, jika kita memilih menggunakan uang untuk memperoduksi bahan mentah, maka kita kehilangan biaya peluang untuk memproduksi barang olahan dari uang tadi. Singkatnya, biaya peluang merupakan biaya yang dikorbankan untuk memperoleh sesuatu yang lain (Amir, 2004). 
Karena perusahaan akan kehilangan keuntungan akan bisnis 'menjual bahan mentah' yang seharusnya diperoleh oleh perusahaan jika perusahaan memilihnya. Jadi laba ekonomi dari bisnis 'pengolahan mineral' adalah laba akunting yaitu Rp. 2,5 miliar - cost opportunity Rp. 200 juta = (Lost Opportunity) Rp. 2,3 miliar setiap bulannya. Jadi tingkat laba ekonomi akan bisnis 'pengolahan mineral ini sebesar 2,3\% tiap bulan. Apabila uang perusahaan itu didapat dari bank dengan bunga $1,0 \%$ per bulan, maka laba ekonominya adalah $1,3 \%$ per bulan.

\section{HASIL DAN PEMBAHASAN}

\section{Hasil}

Untuk mengetahui permasalahan perdagangan luar negeri bauksit, dilakukan analisis LO dengan membandingkan volume ekspor kali harga impor dengan volume ekspor kali harga ekspor. Selisih dari perkalian tersebut adalah kesempatan yang hilang yang bisa diperoleh Indonesia apabila ekspor bauksit dalam bentuk olahan berupa alumina yang harganya sangat tinggi dibandingkan dengan ekspor bauksit dalam bentuk mentah yang harganya sangat rendah. Tujuan dari analisis LO adalah untuk mengetahui seberapa besar kesempatan yang hilang yang bisa diperoleh dari kondisi perdagangan luar negeri bauksit yang dilaksanakan Indonesia selama tahun 2007-2012.

PT. Inalum pada tahun 2007 memproduksi alumunium sekitar 250.000 ton per tahun dan dari jumlah tersebut sebanyak 200.000 ton $(80 \%)$ diekspor, sisanya 50.000 ton untuk memasok di dalam negeri, yang sebenarnya jauh dari angka kebutuhan dalam negeri yang berjumlah 200.000 ton per tahun.
Kebutuhan alumina untuk pabrik alumunium PT. Inalum pada tahun 2007 sekitar 514.180 ton dan seluruhnya diimpor. Negara pemasok alumina terutama adalah Jepang dan Australia. Harga alumina di pasar dunia pada tahun 2007 adalah sekitar US\$ 1.215 per ton, jadi pada tahun 2007 nilai impor alumina adalah sebesar US\$ 625.191.462.

Harga bauksit sangat ditentukan oleh pasar internasional. Beberapa faktor yang dominan memengaruhi harga tersebut adalah naik turunnya permintaan dari pabrik pengolahan alumina dan peleburan aluminium. Pada tahun 2007 harga bauksit mencapai US\$32,00 per ton, alumina US\$1.215,90 per ton dan aluminium US\$2.638,00 per ton (Direktorat Jenderal Mineral dan Batubara, 2013). Pada tahun 2012 terjadi fluktuasi harga, bauksit menjadi US\$32,00 per ton, alumina menjadi US\$1.280,90 dan aluminium menjadi US\$3.720,25 per ton (Tabel 4).

Pada tahun 2007 bauksit diekspor dalam bentuk mentah dengan jumlah 17.031.809 ton. Jika harga bauksit yang diekspor US\$32 per ton, maka jumlah nilai ekspor bauksit adalah US\$545.017.888.

Pada tahun 2007, nilai impor dibandingkan dengan nilai ekspor alumina terdapat selisih (defisit) sebesar US\$ 625.191.462 - US\$ 545.017.888 = US\$ 80.173.574 (atau Rp 801.735.740.000, dianggap kurs 1 US\$ sebesar Rp. 10.000) yang berarti masih ada penggunaan devisa negara untuk pemenuhan bahan baku yang defisit cukup besar.

Dari kondisi perdagangan ekspor dan impor bauksit yang terjadi pada tahun 2007 terdapat kesempatan untuk memperoleh keuntungan yang sangat besar yang bisa diperoleh oleh Indonesia apabila bauksit yang diekspor itu adalah sudah dalam bentuk bauk-

Tabel 4. Harga bauksit, alumina dan aluminium (2007-2012)

\begin{tabular}{ccccccc}
\hline \multirow{2}{*}{ Tahun } & Bauksit & Tren & Alumina & Tren & Aluminium & Tren \\
\cline { 2 - 7 } & US\$/Mt & $(\%)$ & US\$/Mt & $(\%)$ & US\$/Mt & $(\%)$ \\
\hline 2007 & 32,00 & - & $1.215,90$ & - & $2.638,00$ & - \\
2008 & 37,20 & 0,16 & $1.263,70$ & 0,04 & $2.857,00$ & 0,08 \\
2009 & 34,40 & $-0,08$ & 828,70 & $-0,34$ & $3.419,00$ & 0,20 \\
2010 & 29,70 & $-0,14$ & $1.175,80$ & 0,42 & $3.620,00$ & 0,06 \\
2011 & 27,60 & $-0,07$ & $1.428,70$ & 0,22 & $3.915,20$ & 0,08 \\
2012 & 32,00 & 0,16 & $1.280,90$ & $-0,10$ & $3.720,25$ & $-0,05$ \\
\hline Rata-rata & & 0,08 & & 0,05 & & 0,07 \\
\hline
\end{tabular}

Sumber : Direktorat Jenderal Mineral, dan Batubara (2013) 
sit olahan (alumina). LO dari bauksit, pada tahun 2007, adalah sebesar :

$$
\begin{aligned}
\text { LO } 2007= & (\text { Veks X Pim })-(\text { Veks X Peks }) \\
= & (17.031 .809 \times 1.215,90)-(17.031 .809 \\
& x 32)=\text { US\$20.163.958.675 }
\end{aligned}
$$

Pada tahun 2012, nilai impor dibandingkan dengan nilai ekspor alumina terdapat selisih (defisit) sebesar US\$1.281.852.300 - US\$948.889.000 = US\$ 332.963.300 (atau Rp 3.329.633.000.000, dianggap kurs 1 US\$ sebesar Rp. 10.000) yang berarti masih ada penggunaan devisa negara untuk pemenuhan bahan baku yang defisit cukup besar. Terlihat masih minus nya nilai perdagangan bauksit dan alumina bagi Indonesia. Kondisi ini harus diperbaiki, sehingga perdagangannya memberikan nilai surplus bagi negara.

Dari kondisi perdagangan ekspor dan impor bauksit yang terjadi pada tahun 2012 terdapat kesempatan untuk memperoleh keuntungan yang sangat besar yang bisa diperoleh oleh Indonesia apabila bauksit yang diekspor itu adalah sudah dalam bentuk bauksit olahan (alumina). Kesempatan untuk memperoleh keuntungan besar yang hilang LO dari bauksit, pada tahun 2012, adalah sebesar :

$$
\begin{aligned}
\text { LO } 2012= & (\text { Veks X Pim })-(\text { Veks X Peks }) \\
= & (29.688 .890 \times 1.280,90)-(29.688 .890 \\
& \times 32)=\text { US\$ 37.078.455.595 }
\end{aligned}
$$

Seluruh analisis perhitungan LO dan defisit dari perdagangan luar negeri bauksit Indonesia selama tahun 2007 hingga tahun 2012 dapat dilihat pada Tabel 4. Untuk LO (hasilnya dibagi 2, disebabkan setiap 1 ton alumina membutuhkan 2 ton bauksit).

Dari perhitungan analisis LO dan defisit perdagangan luar negeri bauksit selama tahun 2007 hingga tahun 2012 diperoleh hasil :

a. Pada tahun 2007 diperoleh nilai LO sebesar US\$10.081.979.338,00 merupakan hasil dari volume ekspor kali harga impor $(17.031 .809 \times 1.215,90)$ dikurangi volume ekspor kali harga ekspor (17.031.809 x 32) $=$ US\$ 20.163.958.675. Hasil ini selanjutnya dibagi dua karena karena setiap 1 ton alumina membutuhkan bahan baku 2 ton bauksit menjadi (US\$10.081.979.338,00).

b. Pada tahun 2012 diperoleh nilai LO sebesar US\$18.539.227.798,00 merupakan hasil dari volume ekspor kali harga impor $(29.688 .890 \times 1.280,90)$ dikurangi volume eks- por kali harga ekspor $(29.688 .890 \times 32)=$ US\$ 37.078.455.595 (US\$18.539.227.798,00).

c. Selama tahun 2007 hingga tahun 2012 diperoleh rata-rata nilai LO sebesar US\$14.886.140.144,00.

d. Jumlah ekspor bauksit mencapai total 146.938.212,18 ton, namun nilai ekspor yang diperoleh pada tahun tersebut hanya sebesar US\$4.587.949.008,00 disebabkan harga ekspor yang sangat rendah, yaitu rata-rata sebesar US\$32,12 per ton, karena yang dijual berupa bahan mentah. Sementara itu impor alumina hanya mencapai 4.683.066,00 ton dan nilai impor diperoleh sebesar US\$5.647.346.522,00, dengan harga impor yang cukup tinggi mencapai rata-rata US\$1.198,95 per ton, karena yang diimpor berupa bahan olahan.

e. Selama tahun 2007-2012, terdapat defisit neraca perdagangan sebesar US\$176.566.252,00 (nilai ekspor US\$4.587.949.008,00 - nilai impor US\$5.647.346.522,00).

\section{Pembahasan}

a. Sumber daya bauksit dengan kualitas ekspor cukup tinggi (bauksit berkadar tinggi), ternyata tidak memberikan manfaat yang signifikan bagi pendapatan nasional Indonesia. Sampai tahun 2013, seluruh produksi bauksit diekspor dalam bentuk material wantah. Padahal, di sisi lain, industri pengguna mineral bauksit di dalam negeri yang membutuhkan bahan baku hasil olahan (setengah jadi atau bahan jadi) komoditas hasil tambang tersebut, terus tumbuh dan berkembang. Hal ini mengakibatkan impor bahan baku tersebut (alumina) mengalami peningkatan dari 514.180,00 ton tahun 2007 menjadi 1.000.715,00 ton tahun 2012, yang pada akhirnya banyak menyedot devisa negara selama kurun waktu tersebut sebesar US\$5.647.346.522,00. Di samping itu, kondisi tersebut mengurangi daya tahan dan daya saing industri lokal, serta merugikan negara karena nilai tambah pengolahan atau pemurnian komoditas tambang bauksit diambil oleh negara lain sehingga mengurangi nilai dari pendapatan nasional Indonesia.

b. Kondisi perdagangan di sektor mineral bauksit tersebut di atas, sangat merugikan bagi Indonesia sebagai negara produsen bauksit, dan banyak kehilangan kesempatan memperoleh keuntungan dari mineral tersebut. Diberlakukannya Undang-Undang No. 4 tahun 2009 yang menekankan bahwa mulai tahun 2014 semua produk pertambangan harus dijual dalam 
bentuk produk olahan, maka sektor pertambangan bauksit ke depannya akan memperoleh LO yang cukup baik, serta manfaat lainnya, di antaranya adalah, diperolehnya optimalisasi nilai tambang, tersedianya bahan baku bagi industri di dalam negeri (menghemat devisa negara), penyerapan tenaga kerja (peningkatan keahlian, kemampuan, dan penyediaan lapangan kerja terampil), serta peningkatan penerimaan negara (royalti dan pajak).

c. Walaupun volume impor alumina lebih kecil dibanding dengan ekspor bauksit, harga alumina jauh lebih mahal dibanding dengan bauksit. Pada tahun 2012 ekspor bauksit mencapai 29.688.890,70 ton dengan nilai US\$948.889.000,00, dengan harga bauksit tahun 2012 sebesar US\$32,00 per ton. Sementara Indonesia mengimpor alumina yang jumlahnya lebih kecil dibanding ekspor, yaitu sebesar 1.000.715,00 ton dengan nilai sebesar US\$1.281.852.300,00, dengan harga alumina tahun 2012 sebesar US\$1.280,00 per ton. Selama tahun 2007-2012 diperoleh nilai perdagangan yang defisit sebesar US\$176.566.252,00.

d. Selain sudah memproduksi chemical grade alumina (CGA), menurut Tempo Bisnis News (2016), PT.Antam saat ini sedang mengembangkan pabrik pengolahan bauksit menjadi smelter grade alumina (SGA) di Mempawah dengan kapasitas 2.000.000 ton dan membutuhkan bijih bauksit sebanyak 6.000.000 ton, yang akan berproduksi akhir tahun 2017. Pembangunan smelter grade alumina (SGA) ini dilakukan dalam dua tahap, yang setiap tahapannya sanggup memproduksi sebesar 1.000.000 ton SGA, sehingga produk aluminanya dapat memasok kebutuhan bahan baku bagi PT. Inalum yang rata-rata membutuhkan alumina sebesar 500 ribu ton per tahun yang selama ini dipasok dari impor. Karena dibutuhkan investasi yang jumlahnya sangat besar mencapai Rp. 7 triliun (US\$ 500 juta, dengan kurs saat sebesar Rp. 14.000/US\$), saat ini PT. Antam bekerjasama dengan PT. Inalum sedang menjajaki mitra dengan perusahaan asing dari Cina, Rusia dan Timur Tengah.

Seluruh analisis perhitungan LO dari bauksit Indonesia selama tahun 2007 hingga tahun 2012 dapat dilihat pata Tabel 5.

\section{KESIMPULAN DAN SARAN}

\section{Kesimpulan}

Pada tahun 2007 diperoleh nilai LO sebesar US\$10.081.979.338,00 merupakan hasil dari volume ekspor kali harga impor (17.031.809 x $1.215,90)$ dikurangi volume ekspor kali harga ekspor $(17.031 .809 \times 32)=$ US\$ 20.163.958.675. Hasil ini selanjutnya dibagi dua karena karena setiap 1 ton alumina membutuhkan bahan baku 2 ton bauksit menjadi (US\$10.081.979.338,00). Pada tahun 2012 diperoleh nilai LO sebesar US\$18.539.227.798,00 merupakan hasil dari volume ekspor kali harga impor (29.688.890 x $1.280,90)$ dikurangi volume ekspor kali harga ekspor $(29.688 .890 \times 32)=$ US\$ 37.078.455.595 (US\$18.539.227.798,00). Selama tahun 2007 hingga tahun 2012 diperoleh rata-rata nilai LO sebesar US\$14.886.140.144,00 per tahun.

Hasil perhitungan LO bauksit selama tahun 20072012 yang tinggi, atau hilangnya ke-sempatan memperoleh laba yang tinggi akibat bauksit tersebut dijual dalam bentuk mentah, sehingga harga jualnya juga rendah dan diimpor dengan harga yang tinggi, akibatnya tidak memberikan dampak yang signifikan bagi negara dan masyarakat Indonesia, baik secara ekonomi maupun nonekonomi.

Pada tahun 2012, harga bauksit sebesar US\$32,00 per ton, jika diolah menjadi alumina maka akan dapat dijual dengan harga US\$1.280,90 per ton (ada peningkatan sebesar 49,23 kali). Dari alumina jika diolah menjadi aluminium, maka nilai jualnya akan menjadi US\$ 3.720,25 per ton (ada peningkatan sebesar 143,07 kali dibanding dengan dijual dalam bentuk bauksit mentah).

Indonesia sebagai pengekspor bahan mentah bauksit dengan rata-rata nilai ekspor yang diperoleh lebih rendah dari nilai impor (defisit), walaupun volumenya sangat besar karena harganya sangat rendah.

Undang-Undang Pertambangan Nomor 4 Tahun 2009 Tentang Pertambangan Mineral dan Batubara, sudah menegaskan agar produk pertambangan dalam negeri yang salah satunya bauksit, tidak lagi diekspor dalam produk mentah, tetapi harus dilakukan pengolahan menjadi barang jadi atau 


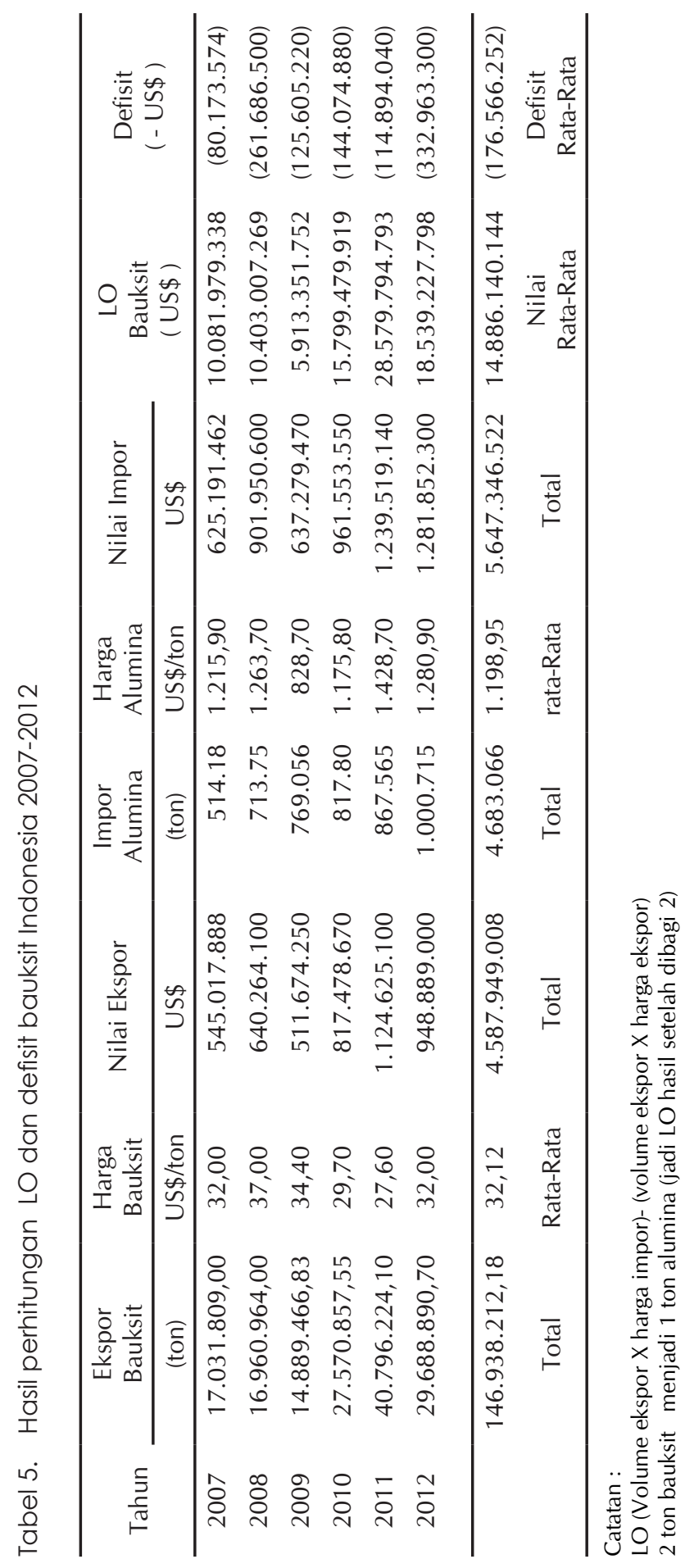


setengah jadi yaitu menjadi alumina, sehingga ada nilai tambah yang bisa didapatkan, sekaligus untuk memenuhi kebutuhan parbrik alumina dan aluminium dalam negeri.

Saat ini PT. ANTAM sedang mengembangkan pabrik pengolahan bauksit menjadi SGA di Mempawah dengan kapasitas 1.200.000 ton yang akan berproduksi tahun 2017 dan CGA di Tayan dengan kapasitas 300.000 ton yang sudah berproduksi mulai tahun 2013 dengan umpan bijih bauksit tercuci sebesar 850.000 ton. Menurut ANTAM, dari setiap ton bauksit yang diproduksi menjadi CGA akan meningkatkan nilai tambah hingga 9,92 kali dibandingkan jika hanya menjual bauksit dalam bentuk bijih, hal ini akan mengurangi nilai LO ANTAM sebesar US\$200 juta apabila ekspor dalam bentuk bijih dan mengurangi nilai LO yang selama ini dihadapi Indonesia dalam sektor pertambangan bauksit.

\section{Saran}

Kebijakan yang mewajibkan pemegang IUP dan IUPK meningkatkan nilai tambah hasil produksinya sebelum diekspor harus benar-benar dilaksanakan, agar ada keuntungan yang bisa didapatkan dari hasil tambang dalam negeri. Selama ini cadangan tambang Indonesia dikuras negara lain dan diekspor mentah, sementara Indonesia tidak mendapatkan nilai tambah atau keuntungan hasil produksi tambang tersebut.

Sangat tepat dan beralasan jika ke depannya rencana pembangunan fasilitas pengolahan dan pemurnian bauksit di Indonesia (khususnya di Kalimantan Barat) dapat diwujudkan dengan segera, sehingga dikemudian hari Indonesia bisa mendapat LO atau kesempatan mendapat keuntungan yang sangat besar dari perdagangan luar negeri bauksit dan nilai perdagangan ekspor bauksit menjadi positif.

Apabila industri pengolahan bauksit menjadi alumina dapat segera dilaksanakan, kemungkinan akan dapat meningkatkan nilai ekspor perdagangan bauksit nasional, memperoleh surplus yang sangat besar, meningkatnya pendapatan nasional, serta meningkatkan tingkat LO bauksit Indonesia.

Adanya industri pengolahan bauksit di dalam negeri, di samping dapat meningkatkan nilai ekspor juga akan mendapatkan LO sangat besar dan Indonesia dapat ikut serta berperan dalam memasok kebutuhan alumina dunia yang semakin meningkat akibat pesatnya pembangunan di negara-negara berkembang maupun negara maju yang membutuhkan produk aluminium. Jika selama ini Indonesia hanya mengirimkan produksi bijih bauksit, maka akan sangat bijak, jika Indonesia dapat mengolahnya terlebih dahulu, sehingga dapat meningkatkan nilai jualnya

Indikator-indikator yang terkait secara tidak langsung untuk memperbaiki LO perdagang-an bauksit hendaknya dapat dilaksanakan, seperti:

a) Pemerintah daerah harus menyelaraskan segala rupa kebijakan daerahnya dengan pusat, dalam memberikan kepastian hukum bagi investor, sebagai dampak dari otonomi daerah agar tidak terjadi adanya tumpang tindih lahan IUP, tata guna lahan dan proses perijinan (UU No 23 Tahun 2014 Tentang Otonomi Daerah).

b) Adanya insentif untuk percepatan pembangunan smelter berupa tax holiday dan pembebasan bea masuk barang modal.

c) Adanya kawasan ekonomi khusus untuk mendukung proyek-proyek smelter.

d) Terdapat kaitan hulu-hilir industri mineral nasional yang terjalin dengan kokoh.

e) Meningkatkan keterbatasan infrastruktur yang tersedia di lokasi proyek smelter.

f) Dukungan dalam hal mengantisipasi peningkatan kebutuhan dari para pemangku kepentingan yang dapat menyebabkan ongkos produksi menjadi besar.

Mengingat barang tambang bauksit merupakan daya alam yang tidak dapat diperbaharui, hendaknya pemerintah konsisten dan lebih tegas dalam mengawasi pelaksanaan UU No. 4 Tahun 2009 dan Permen No. 7 Tahun 2012 tentang Peningkatan Nilai Tambah, sehingga Indonesia dapat mengekspor hasil olahan dalam bentuk alumina ataupun aluminium, bukan barang mentah dalam bentuk bauksit. Dengan begitu Indonesia bisa mengekspor dengan harga yang berkali-kali lipat dari harga bauksit itu sendiri tanpa harus mengimpor kembali.

\section{UCAPAN TERIMA KASIH}

Pada kesempatan ini penulis mengucapkan terima kasih kepada Kepala Dinas Pertambangan dan Energi Provinsi Kalimantan Barat beserta stafnya yang telah memberikan data dan informasi mengenai industri bauksit dan alumina yang sangat bermanfaat dalam mendukung kajian ini. Semoga kajian ini memberikan manfaat bagi semua pihak yang berkepentingan terhadap industri dan pertambangan bauksit dan industri pengolahan alumina 
khususnya di Provinsi Kalimantan Barat, umumnya di Indonesia.

\section{DAFTAR PUSTAKA}

Adie Ahmeth, 2010. Makalah dampak globalisasi terhadap terekonomian. (Online), (http://om Adie ahmeth.blogspot.com, diunduh pada tanggal 15 April 2015).

Amir M.S, 2004. Seluk beluk dan teknik perdagangan luar negeri, Jakarta. 389 halaman.

Anonim, 2014. Undang-Undang No 23 Tahun 2014 tentang Pemerintahan Daerah.

Antoni, 2008. Investasi langsung asing dan perdagangan: bukti empiris di Indonesia. Jurnal Ekonomi Bisnis dan Koperasi. Vol.10 No.2, Oktober2008.

Badan Pusat Statistik, 2013a. Statistik industri besar sedang, 2007-2013, Jakarta. 522 halaman

Badan Pusat Statistik, 2013b. Statistik impor 2007-2013, Jakarta. 143 halaman.

Badan Pusat Statistik, 2013c. Statistik ekspor 2007-2013, Jakarta. 209 halaman.

Bank Indonesia, 2015. Laporan perkonomian Indonesia. Jakarta: BI.

Bank Indonesia, 2015. Data Series Triwulan Investasi Langsung Asing 1990-2014. Jakarta: BI

Dinas Pertambangan Propinsi Kepulauan Riau, 2013 Pertambangan Propinsi Kepulauan Riau. Kepulauan Riau. 92 halaman.

Dinas Pertambangan Propinsi Kalimantan Barat, 2013. Pertambangan Propinsi Kalimantan Barat, Pontianak. 118 halaman.

Direktorat Jenderal Mineral dan Batu Bara, 2013. Statistik Potensi dan Neraca Sumber Daya Mineral, dan Batu Bara, Jakarta. 97 halaman.

Hailu, Z.N. 2010. Impact of foreign direct investment on trade of African Countries. International Journal of Economics and Finance, Vol. 2, No. 3; August 2010.

Kementerian Perdagangan, 2013. Perdagangan ekspor dan impor Indonesia, Pusat data dan Informasi Kementerian Perdagangan, Jakarta. 203 halaman.
Mineral Information Institute, 2013. World bauxite producers. 45 halaman.

Pramudita, R.S. 2012. Analisis pengaruh keterbukaan perdagangan terhadap pertumbuhan ekonomi, penanaman modal asing, dan tenaga kerja industri besar dan sedang dengan pendekatan vector autoregessive [Skripsi]. Jakarta: Sekolah Tinggi Ilmu Statistik.

Prasetyawati, M.D. 2012. Kajian utang pemerintah indonesia: keter-kaitannya terhadap perekonomian dan faktor- faktor yang memengaruhi debt ratio pemerintah periode triwulan III 1998- triwulan III 2011 [Skripsi]. Jakarta: Sekolah Tinggi Ilmu Statistik.

Pusat Sumber Daya Geologi, 2013. Sumber daya mineral dan batubara di Indonesia, Bandung. 192 halaman.

PT. Antam, 2011. Nilai tambah dalam industri penambangan dan pengolahan logam di Indonesia, Studi Kasus "Chemical Grade Alumina Project", Jakarta, 2011.

Salvatore, D., 2007. International economics. PrenticeHall.

Sugiarto dan Herlambang T., 2006. Ekonomi makro teori, analisis dan kebijakan dalam bisnis manajemen dan keuangan. Gramedia, Jakarta. 296 halaman.

Tambunan Th.T. dan Kuznets, 2004. Perdagangan Internasional dan Neraca Pembayaran, Teori dan Temuan Empiris. LP3ES Jakarta. 217 halaman.

Tempo.Co Bisnis News. (2015, 15 Oktober). Bangun Smelter Grade Alumina Refinery, PT. Antam dan PT. Inalum Sepakat Bentuk Perusahaan Patungan. Diunduh tanggal 14 Januari 2016 dari http://bisnis.news.tempo.co.id/news/read/426512-bangun smelter grade refinery-pt antam-dan pt inalumsepakat-bentuk-perusahaan-patungan.

Tulus, T., dan Simon, K., 2004. Perdagangan internasional dan neraca pembayaran, teori dan temuan empiris. LP3ES Jakarta. 217 halaman.

Viva Bisnis News, 2012. BI ungkap penyebab ketimpangan ekspor dan impor RI. Diunduh tanggal 1Maret 2015 dari http://bisnis.news.viva.co.id/news/ $\mathrm{read} / 366817-b i-u n g k a p-p e n y e b a b-k e t i m p a n g a n-$ ekspor-dan-impor-ri. 
